\title{
Cadmium Accumulation Characteristics of Lycopersicon esculentum Seedlings
}

\author{
Hongyan $\mathrm{Li}^{1, \mathrm{a}}$, Jianhua $\mathrm{Li}^{2, \mathrm{~b}}$, Huashan $\mathrm{Lian}^{3, \mathrm{c}}$, Wei Jiang ${ }^{4, \mathrm{~d}}$ and Lijin $\operatorname{Lin}^{1, \mathrm{e}^{*}}$ \\ ${ }^{1}$ Institute of Pomology and Olericulture, Sichuan Agricultural University, Chengdu, Sichuan, China \\ ${ }^{2}$ Sichuan Ya'an Municipal Product Quality Supervision \& Inspection Institute, Ya'an, Sichuan, China \\ ${ }^{3}$ Subcollege of Garden and Horticulture, Chendu Agricultural College, Chengdu, Sichuan, China \\ ${ }^{4}$ College of Chemistry and Life Science, Chengdu Normal University, Chengdu, Sichuan, China

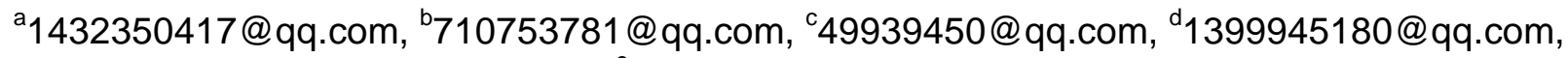 \\ ellj800924@163.com
}

${ }^{*}$ Corresponding author. Hongyan Li, Jianhua Li and Huashan Lian contributed equally to this work.

Keywords: Lycopersicon esculentum; Seedling; Cadmium; Growth

Abstract: The cadmium (Cd) accumulation characteristics of Lycopersicon esculentum seedlings were studied by the pot experiment, and different soil Cd concentrations $(0,1,5,10,15$ and $20 \mathrm{mg} / \mathrm{kg}$ ) were used. With the increase of soil Cd concentration, the biomass and photosynthetic pigment content of $L$. esculentum seedlings had the decreasing trend. The SOD, POD and CAT activities of L. esculentum seedlings had the increase trend when the soil Cd concentration was not more than $5 \mathrm{mg} / \mathrm{kg}$, and decreased when the soil Cd concentration was higher than $5 \mathrm{mg} / \mathrm{kg}$. The soluble protein contents of $L$. esculentum seedlings had the decreasing trend with the increase of soil $\mathrm{Cd}$ concentrations. The $\mathrm{Cd}$ contents in different organs L. esculentum seedlings were ranked as root $>$ leaf $>$ shoot $>$ stem. With the increase of $\mathrm{Cd}$ concentrations in soil, the $\mathrm{Cd}$ contents in roots, stems, leaves and shoots of $L$. esculentum seedlings increased. Therefore, the soil Cd inhibited the growth of L. esculentum seedlings.

\section{Introduction}

Lycopersicon esculentum is one of the most important vegetable crops in the word [1]. However, the heavy metal polluted vegetable gardens have affected the production of L. esculentum, especially cadmium (Cd) [2-3]. The $\mathrm{Cd}$ is the most bio-toxic heavy metal elements, and has strong chemical activity, mobility, long-lasting toxicity in the environment [4]. The Cd inhibits the growth of plants, especially in high Cd concentration, the growth of plants was significantly inhibited, and the structure of tissues was obviously deformed [5-6]. However, there are few reports on Cd accumulation characteristics of L. esculentum. In this study, different concentrations of $\mathrm{Cd}(0,1,5,10,15$ and 20 $\mathrm{mg} / \mathrm{kg}$ ) were added into soil, and planted the seedlings of L. esculentum. The Cd accumulation characteristics of $L$. esculentum seedlings were studied to provide the reference for reducing $\mathrm{Cd}$ accumulation in L. esculentum.

\section{Materials and Methods}

Materials. The Inceptisol soil samples (purple soil in the Genetic Soil Classification of China) were collected from the Chengdu campus farm of Sichuan Agricultural University $\left(30^{\circ} 42^{\prime} \mathrm{N}, 103^{\circ} 51^{\prime} \mathrm{E}\right)$ in April 2017. The basic properties of the soil were $\mathrm{pH} 6.94$, organic matter $17.54 \mathrm{~g} / \mathrm{kg}$, total nitrogen $3.63 \mathrm{~g} / \mathrm{kg}$, total phosphorus $0.38 \mathrm{~g} / \mathrm{kg}$, total potassium $17.54 \mathrm{~g} / \mathrm{kg}$, alkali soluble nitrogen 195.00 $\mathrm{mg} / \mathrm{kg}$, available phosphorus $6.25 \mathrm{mg} / \mathrm{kg}$ and available potassium $191.13 \mathrm{mg} / \mathrm{kg}$. The total Cd content was $0.103 \mathrm{mg} / \mathrm{kg}$, and the bioavailable Cd content was $0.022 \mathrm{mg} / \mathrm{kg}$ [7]. The seeds of L. esculentum buy from the market, and were sown in nutrient soil in April 2017.

Experimental Design. The soil samples were air dried and sieved to $5 \mathrm{~mm}$ in April 2017, then 3.0 $\mathrm{kg}$ of the air-dried soil was weighed into polyethylene pots $(15 \mathrm{~cm}$ tall, $18 \mathrm{~cm}$ diameter $)$, and $\mathrm{Cd}$ was added to the soils as $\mathrm{CdCl}_{2} \cdot 2.5 \mathrm{H}_{2} \mathrm{O}$ at $0,1,5,10,15$ and $20 \mathrm{mg} / \mathrm{kg}$ [8]. The soil moisture content was 
maintained at $80 \%$ of field capacity for 4 weeks, and then the soil in each pot was mixed. Three uniform seedlings with four euphyllas were transplanted into each pot in May 2017. Each treatment was repeated three times making a total of 18 pots, and put in a completely randomized design with $10 \mathrm{~cm}$ spacing between pots. The soil moisture content was maintained at $80 \%$ of field capacity until the plants were harvested.

Two months after planting (July 2017), the upper mature leaves of plants were collected to determine the photosynthetic pigment (chlorophyll $a$, chlorophyll $b$, total chlorophyll and carotenoid) contents [9]. The upper young leaves $(2 \mathrm{~cm}$ in length) were collected to determine the superoxide dismutase (SOD) activity, peroxidase (POD) activity, catalase (CAT) activity and soluble protein content [9]. Then, the whole plants were then gently removed, the roots, stems and leaves were washed with tap water followed by deionized water, and dried at $80^{\circ} \mathrm{C}$ to constant weight. The biomass was then measured of roots, stems and leaves. The dried tissue samples were finely ground and sieved through a $0.149 \mathrm{~mm}$ mesh nylon sieve for chemical analysis. Samples $(0.5 \mathrm{~g})$ were digested in $\mathrm{HNO}_{3} / \mathrm{HClO}_{4}(4: 1, \mathrm{v} / \mathrm{v})$, and then the volume was brought to $50 \mathrm{~mL}$ with deionized water [10]. The $\mathrm{Cd}$ concentrations in roots, tubers and leaves were determined using an iCAP 6300 ICP-MS spectrometer (Thermo Scientific, Waltham, MA, USA). The translocation factor (TF) is defined as Cd content in shoots/Cd content in roots [11].

Statistical Analyses. Statistical analyses were conducted using SPSS 13.0 statistical software (IBM, Chicago, IL, USA). Data were analyzed by one-way analysis of variance with least significant difference (LSD) at the $\mathrm{p}=0.05$ confidence level.

\section{Results and Discussion}

Biomass of L. esculentum Seedlings. With the increase of Cd concentrations in soil, the root, stem leaf and shoot biomasses of L. esculentum seedlings had a decreasing trend (Table 1). So, different concentrations of Cd inhibited the growth of L. esculentum seedlings. When the soil Cd concentrations were $1,5,10,15$ and $20 \mathrm{mg} / \mathrm{kg}$, the root biomass of L. esculentum seedlings were decreased by $4.76 \%$ $(p>0.05), 7.14 \%(p>0.05), 30.95 \%(p<0.05), 33.33 \%(p<0.05)$ and $35.71 \%(p<0.05)$, respectively, compared with the control, and the shoot biomass were decreased by $5.71 \%(p<0.05)$, $24.76 \%(p<0.05), 29.52 \%(p<0.05), 34.29 \%(p<0.05)$ and $41.43 \%(p<0.05)$, respectively. The root/shoot ratio of $L$. esculentum seedlings was ranked as $5 \mathrm{mg} / \mathrm{kg}>20 \mathrm{mg} / \mathrm{kg}>15 \mathrm{mg} / \mathrm{kg}>0 \mathrm{mg} / \mathrm{kg}$ $=1 \mathrm{mg} / \mathrm{kg}>10 \mathrm{mg} / \mathrm{kg}$ (Table 1$)$.

Table 1 Biomass of L. esculentum seedlings

\begin{tabular}{|c|c|l|c|c|c|}
\hline Treatments & $\begin{array}{c}\text { Roots } \\
\text { (g/plant) }\end{array}$ & $\begin{array}{c}\text { Stems } \\
\text { (g/plant) }\end{array}$ & $\begin{array}{c}\text { Leaves } \\
\text { (g/plant) }\end{array}$ & $\begin{array}{c}\text { Shoots } \\
\text { (g/plant) }\end{array}$ & Root/shoot ratio \\
\hline 0 & $0.42 \pm 0.02 \mathrm{a}$ & $0.92 \pm 0.05 \mathrm{a}$ & $1.18 \pm 0.04 \mathrm{a}$ & $2.10 \pm 0.06 \mathrm{a}$ & 0.201 \\
\hline 1 & $0.40 \pm 0.02 \mathrm{a}$ & $0.89 \pm 0.02 \mathrm{a}$ & $1.09 \pm 0.05 \mathrm{~b}$ & $1.98 \pm 0.07 \mathrm{~b}$ & 0.201 \\
\hline 5 & $0.39 \pm 0.02 \mathrm{a}$ & $0.68 \pm 0.02 \mathrm{~b}$ & $0.91 \pm 0.03 \mathrm{c}$ & $1.58 \pm 0.04 \mathrm{c}$ & 0.246 \\
\hline 10 & $0.29 \pm 0.01 \mathrm{~b}$ & $0.61 \pm 0.01 \mathrm{c}$ & $0.87 \pm 0.03 \mathrm{~cd}$ & $1.48 \pm 0.04 \mathrm{~cd}$ & 0.197 \\
\hline 15 & $0.28 \pm 0.02 \mathrm{~b}$ & $0.57 \pm 0.02 \mathrm{~cd}$ & $0.81 \pm 0.02 \mathrm{~d}$ & $1.38 \pm 0.05 \mathrm{~d}$ & 0.202 \\
\hline 20 & $0.27 \pm 0.01 \mathrm{~b}$ & $0.54 \pm 0.02 \mathrm{~d}$ & $0.69 \pm 0.04 \mathrm{e}$ & $1.23 \pm 0.02 \mathrm{e}$ & 0.217 \\
\hline
\end{tabular}

Values are means \pm standard errors. Means with the same letter within each column are not significantly different at $p<0.05$.

Photosynthetic Pigment Content in L. esculentum Seedlings. The chlorophyll a, chlorophyll b, total chlorophyll and carotenoid contents of L. esculentum seedlings decreased with the increase of Cd concentration in soil (Table 2). When the soil Cd concentrations were 1, 5, 10, 15 and $20 \mathrm{mg} / \mathrm{kg}$, the total chlorophyll contents of L. esculentum seedlings were decreased by 3.33\% $(p>0.05), 9.52 \%(p<$ $0.05), 11.43 \%(p<0.05), 20.95 \%(p<0.05)$ and $27.62 \%(p<0.05)$ respectively, compared with the control, and the carotenoid contents decreased by $1.96 \%(p>0.05), 5.88 \%(p>0.05), 7.84 \%(p>$ $0.05), 17.65 \%(p<0.05)$ and $23.53 \%(p<0.05)$, respectively. The chlorophyll a/b of L. esculentum 
seedlings had no obvious changes in different concentrations of soil $\mathrm{Cd}$.

Table 2 Photosynthetic pigment content in L. esculentum seedlings

\begin{tabular}{|c|c|c|c|c|c|}
\hline Treatments & $\begin{array}{c}\text { Chlorophyll } a \\
(\mathrm{mg} / \mathrm{g})\end{array}$ & $\begin{array}{c}\text { Chlorophyll } b \\
(\mathrm{mg} / \mathrm{g})\end{array}$ & $\begin{array}{c}\text { Total chlorophyll } \\
(\mathrm{mg} / \mathrm{g})\end{array}$ & Chlorophyll a/b & $\begin{array}{c}\text { Carotenoid } \\
(\mathrm{mg} / \mathrm{g})\end{array}$ \\
\hline 0 & $1.47 \pm 0.04 \mathrm{a}$ & $0.63 \pm 0.01 \mathrm{a}$ & $2.10 \pm 0.06 \mathrm{a}$ & 2.34 & $0.51 \pm 0.03 \mathrm{a}$ \\
\hline 1 & $1.42 \pm 0.03 \mathrm{a}$ & $0.61 \pm 0.02 \mathrm{ab}$ & $2.03 \pm 0.05 \mathrm{a}$ & 2.34 & $0.50 \pm 0.03 \mathrm{a}$ \\
\hline 5 & $1.32 \pm 0.02 \mathrm{~b}$ & $0.58 \pm 0.001 \mathrm{bc}$ & $1.90 \pm 0.02 \mathrm{~b}$ & 2.30 & $0.48 \pm 0.01 \mathrm{a}$ \\
\hline 10 & $1.30 \pm 0.04 \mathrm{~b}$ & $0.56 \pm 0.01 \mathrm{c}$ & $1.86 \pm 0.06 \mathrm{~b}$ & 2.34 & $0.47 \pm 0.01 \mathrm{a}$ \\
\hline 15 & $1.16 \pm 0.02 \mathrm{c}$ & $0.50 \pm 0.01 \mathrm{~d}$ & $1.66 \pm 0.01 \mathrm{c}$ & 2.32 & $0.42 \pm 0.01 \mathrm{~b}$ \\
\hline 20 & $1.06 \pm 0.03 \mathrm{~d}$ & $0.46 \pm 0.02 \mathrm{e}$ & $1.52 \pm 0.01 \mathrm{~d}$ & 2.33 & $0.39 \pm 0.01 \mathrm{~b}$ \\
\hline
\end{tabular}

Values are means \pm standard errors. Means with the same letter within each column are not significantly different at $p<0.05$.

Antioxidant Enzyme Activity of $L$. esculentum Seedlings. When the soil Cd concentrations were 1,5 and $10 \mathrm{mg} / \mathrm{kg}$, the SOD activity of L. esculentum seedlings improved by $21.52 \%(p<0.05)$, $71.85 \%(p<0.05)$ and $4.38 \%(p>0.05)$, respectively, compared with the control (Table 3$)$. However, 10 and $20 \mathrm{mg} / \mathrm{kg}$ soil Cd reduced the SOD activity of $L$. esculentum seedlings by $16.91 \%(p<0.05)$ and $24.15 \%(p<0.05)$, respectively, compared with the control. When the soil Cd concentrations were 1 and $5 \mathrm{mg} / \mathrm{kg}$, the POD activity of $L$. esculentum seedlings were had no significant differences compared with the control, and 10,15 and $20 \mathrm{mg} / \mathrm{kg}$ soil Cd reduced the POD activity by $14.65 \%$ ( $p<$ $0.05), 32.96 \%(p<0.05)$ and $38.20 \%(p<0.05)$, respectively, compared with the control. The CAT activities of $L$. esculentum seedlings were improved by 1 and $5 \mathrm{mg} / \mathrm{kg}$ soil $\mathrm{Cd}$, and reduced by 10,15 and $20 \mathrm{mg} / \mathrm{kg}$ soil Cd. With the increase of soil Cd concentrations, the soluble protein contents had the decreasing trend (Table 3 ).

Table 3 Antioxidant enzyme activity of L. esculentum seedlings

\begin{tabular}{|c|c|c|c|c|}
\hline Treatments & $\begin{array}{c}\text { SOD activity } \\
(\mathrm{U} / \mathrm{g})\end{array}$ & $\begin{array}{c}\text { POD activity } \\
(\mathrm{U} / \mathrm{g} / \mathrm{min})\end{array}$ & $\begin{array}{c}\text { CAT activity } \\
(\mathrm{mg} / \mathrm{g} / \mathrm{min})\end{array}$ & $\begin{array}{c}\text { Soluble protein content } \\
(\mathrm{mg} / \mathrm{g})\end{array}$ \\
\hline 0 & $102.02 \pm 2.30 \mathrm{c}$ & $1082.98 \pm 29.62 \mathrm{a}$ & $5.33 \pm 0.12 \mathrm{c}$ & $11.37 \pm 0.07 \mathrm{a}$ \\
\hline 1 & $123.97 \pm 9.33 \mathrm{~b}$ & $1118.29 \pm 49.65 \mathrm{a}$ & $5.77 \pm 0.11 \mathrm{~b}$ & $10.45 \pm 0.18 \mathrm{~b}$ \\
\hline 5 & $175.32 \pm 6.77 \mathrm{a}$ & $1075.04 \pm 29.18 \mathrm{a}$ & $6.31 \pm 0.13 \mathrm{a}$ & $9.82 \pm 0.02 \mathrm{c}$ \\
\hline 10 & $106.49 \pm 1.70 \mathrm{c}$ & $924.36 \pm 10.79 \mathrm{~b}$ & $3.33 \pm 0.08 \mathrm{~d}$ & $7.74 \pm 0.09 \mathrm{~d}$ \\
\hline 15 & $84.77 \pm 5.59 \mathrm{~d}$ & $726.07 \pm 23.08 \mathrm{c}$ & $3.30 \pm 0.06 \mathrm{~d}$ & $6.57 \pm 0.07 \mathrm{e}$ \\
\hline 20 & $77.38 \pm 3.70 \mathrm{~d}$ & $669.23 \pm 16.05 \mathrm{~d}$ & $3.10 \pm 0.05 \mathrm{~d}$ & $4.11 \pm 0.10 \mathrm{f}$ \\
\hline
\end{tabular}

Values are means \pm standard errors. Means with the same letter within each column are not significantly different at $p<0.05$.

Cd Content in L. esculentum Seedlings. The Cd contents in different organs L. esculentum seedlings were ranked as root $>$ leaf $>$ shoot $>$ stem (Table 4). With the increase of Cd concentrations in soil, the Cd contents in roots, stems, leaves and shoots of $L$. esculentum seedlings increased. When the soil Cd concentrations were $1,5,10,15$ and $20 \mathrm{mg} / \mathrm{kg}$, the Cd contents in roots of L. esculentum seedlings were $3.42,17.09,32.34,41.24$ and 49.45 times respectively than the control, and the $\mathrm{Cd}$ contents in shoots were $4.95,9.87,14.67,19.79$ and 22.54 times respectively than the control. The order of TF was $1 \mathrm{mg} / \mathrm{kg}>0 \mathrm{mg} / \mathrm{kg}>5 \mathrm{mg} / \mathrm{kg}>15 \mathrm{mg} / \mathrm{kg}>20 \mathrm{mg} / \mathrm{kg}>10 \mathrm{mg} / \mathrm{kg}$ (Table 4).

\section{Conclusions}

With the increase of soil $\mathrm{Cd}$ concentration, the biomass and photosynthetic pigment content of $L$. esculentum seedlings had the decreasing trend. The SOD, POD and CAT activities of L. esculentum seedlings had the increase trend when the soil Cd concentration was not more than $5 \mathrm{mg} / \mathrm{kg}$, and decreased when the soil Cd concentration was higher than $5 \mathrm{mg} / \mathrm{kg}$. The soluble protein contents of $L$. 
esculentum seedlings had the decreasing trend with the increase of soil $\mathrm{Cd}$ concentrations. The $\mathrm{Cd}$ contents in different organs L. esculentum seedlings were ranked as root $>$ leaf $>$ shoot $>$ stem. With the increase of $\mathrm{Cd}$ concentrations in soil, the $\mathrm{Cd}$ contents in roots, stems, leaves and shoots of $L$. esculentum seedlings increased. Therefore, the soil Cd inhibited the growth of L. esculentum seedlings.

Table 4 Cd content in L. esculentum seedlings

\begin{tabular}{|c|c|c|c|c|c|}
\hline Treatments & $\begin{array}{c}\text { Roots } \\
(\mathrm{mg} / \mathrm{kg})\end{array}$ & $\begin{array}{c}\text { Stems } \\
(\mathrm{mg} / \mathrm{kg})\end{array}$ & $\begin{array}{c}\text { Leaves } \\
(\mathrm{mg} / \mathrm{kg})\end{array}$ & $\begin{array}{c}\text { Shoots } \\
(\mathrm{mg} / \mathrm{kg})\end{array}$ & TF \\
\hline 0 & $2.40 \pm 0.10 \mathrm{f}$ & $0.80 \pm 0.07 \mathrm{f}$ & $3.05 \pm 0.14 \mathrm{f}$ & $2.07 \pm 0.12 \mathrm{f}$ & 0.863 \\
\hline 1 & $8.21 \pm 0.92 \mathrm{e}$ & $4.19 \pm 0.24 \mathrm{e}$ & $15.19 \pm 1.17 \mathrm{e}$ & $10.24 \pm 0.82 \mathrm{e}$ & 1.247 \\
\hline 5 & $41.02 \pm 3.68 \mathrm{~d}$ & $7.93 \pm 0.52 \mathrm{~d}$ & $29.69 \pm 2.36 \mathrm{~d}$ & $20.43 \pm 1.58 \mathrm{~d}$ & 0.498 \\
\hline 10 & $77.61 \pm 2.76 \mathrm{c}$ & $11.59 \pm 0.54 \mathrm{c}$ & $43.46 \pm 3.03 \mathrm{c}$ & $30.36 \pm 2.06 \mathrm{c}$ & 0.391 \\
\hline 15 & $98.97 \pm 5.15 \mathrm{~b}$ & $13.85 \pm 0.75 \mathrm{~b}$ & $59.94 \pm 4.10 \mathrm{~b}$ & $40.97 \pm 2.56 \mathrm{~b}$ & 0.414 \\
\hline 20 & $118.69 \pm 9.04 \mathrm{a}$ & $14.87 \pm 0.91 \mathrm{a}$ & $71.66 \pm 4.34 \mathrm{a}$ & $46.65 \pm 3.99 \mathrm{a}$ & 0.393 \\
\hline
\end{tabular}

Values are means \pm standard errors. Means with the same letter within each column are not significantly different at $p<0.05$.

\section{References}

[1] P.B. Wang, J.M. Li, J.J. Ding, G.Y. Liu, T.H. Pan, Q.J. Du and Y.B. Chang: Scientia Agricultural Sinica Vol. 48 (2015), p. 314.

[2] Y.Z. Zhou, S.Q. Song, C.B. Zhang, X.Q. Yang and C.L. Liu: Geological Bulletin of China Vol. 24 (2005), p. 940.

[3] C.Y. Liu, Y.F. Zhang and J. Teng: Pollution Control Technology Vol. 19 (2006), p. 42.

[4] Y.H. Xiong and X.E Yang: Journal of Anhui Agricultural Sciences Vol. 34 (2006), p. 2969.

[5] Y. Li, J.J. Li and X.H. Wei: Acta Prataculturae Sinica Vol. 18 (2009), p. 186.

[6] F.B. Wu, G.P. Zhang and P. Dominy: Environmental and Experimental Botany Vol. 50 (2003), p. 67.

[7] Y. Liu, L. Lin, Q. Jin and X. Zhu: Environmental Progress \& Sustainable Energy Vol. 34 (2015), p. 663.

[8] J. Shi, R.P. Hu, X.D. Chu, C.C. Li, J. Zhang and L.J. Lin: Shanxi Journal of Agricultural Sciences Vol. 62 (2015), p. 1.

[9] Z.B. Hao, J. Chang and Z. Xu: Plant Physiology Experiment (Harbin Institute of Technology Press, China 2004).

[10] G.S. Liu: Soil Physical and Chemical Analysis \& Description of Soil Profiles (Standards Press of China, Beijing,China 1996).

[11] A. Caunii, A. Negrea, M. Pentea, I. Samfira, M. Motoc and M. Butnariu: Revista de Chimie (Bucharest) Vol. 66 (2015), p. 382. 